\title{
Notes on the Vertical Deformations of the Ground Surface in the Central Part of the City of Tokyo.
}

\author{
By \\ Naomi Mryabe and Akio Kataoka. \\ Geographic Survey Institute, Chiba.
}

\begin{abstract}
1. The vertical displacements of the ground surface in the central part of the city of Tokyo, which have been detected by levelling surveys repeated recently, consist of two components, namely, the sinking due to the shrinkage of the soft superficial soil layer and the displacement resulting from tilt of the underlying layer of harder material. The former is progressive as a whole, while the latter is quasi-periodic with respect to time. The vertical displacements measured for longer intervals of time are proceeding in one direction, although those measured for shorter intervals show more or less irregular fluctuations.

2. As a whole, the rate of sinking has been evidently decreasing.

3. The rate of sinking during the intervals involving summer is larger than that involving winter.
\end{abstract}

In the present paper are given the results of analysis of the materials concerning the vertical movements of the surface of the ground in Marunouchi and Hibiya, in the central part of the city of Tokyo. The vertical displacements were deduced from the results of repeated precise levellings which were made referring to special bench-marks

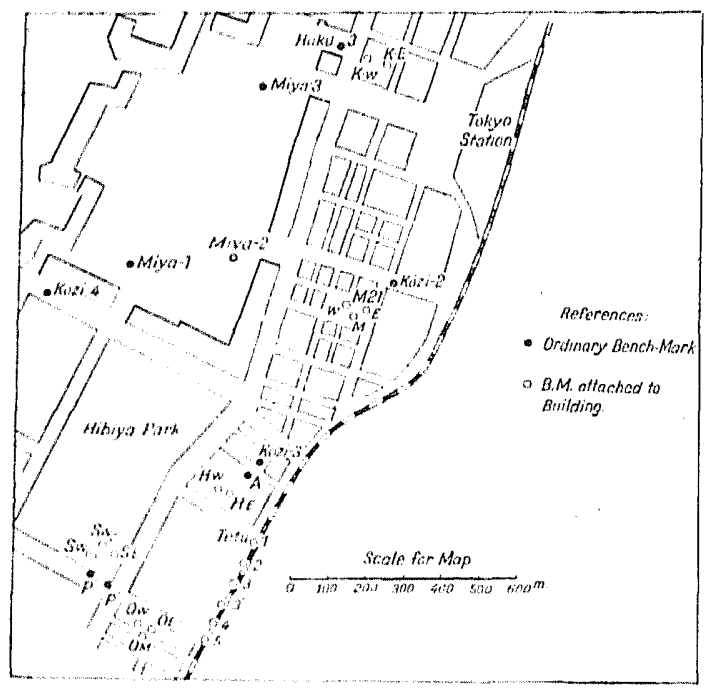

Fig. 1a. Distribution of bench-marks. fixed to the wall of several selected buildings in the area, as well as to several other ordinary bench-marks. The locations of the

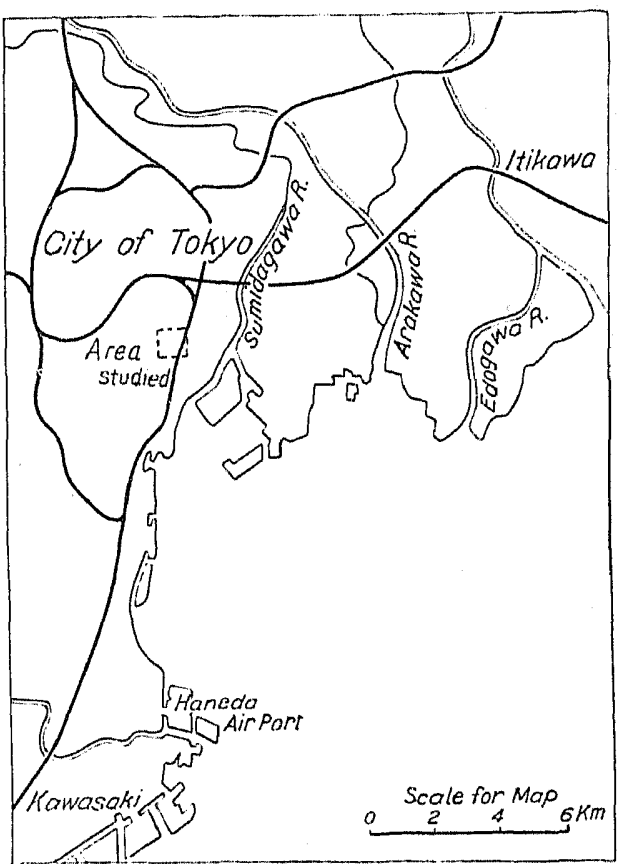

Fig. 1 b. Reference to the area under consideration. 
Table I. Vertical Displacements of Bench-Marks in Hibiya and Marunouchi Area (in mm.).

\begin{tabular}{|c|c|c|c|c|c|c|c|c|c|c|c|c|c|}
\hline $\mathrm{I}$ & & $\begin{array}{c}\text { May } \\
1938 \\
\text { ? } \\
\text { Nov. } \\
1938\end{array}$ & $\begin{array}{c}\text { Nov. } \\
1938 \\
\text { k } \\
\text { Feb. } \\
1939\end{array}$ & $\begin{array}{c}\text { Feb. } \\
1939 \\
? \\
\text { June } \\
1939 \\
\end{array}$ & $\begin{array}{c}\text { June } \\
1939 \\
? \\
\text { Nov. } \\
1939 \\
\end{array}$ & $\begin{array}{c}\text { Nov: } \\
1939 \\
\text { April } \\
1940 \\
\end{array}$ & $\begin{array}{c}\text { April } \\
1940 \\
\text { Oct. } \\
1940\end{array}$ & $\begin{array}{c}\text { Oct. } \\
1940 \\
\text { ? } \\
\text { Apri1 } \\
1942 \\
\end{array}$ & $\begin{array}{c}\text { April } \\
1942 \\
\text { Sept. } \\
1942 \\
\end{array}$ & $\begin{array}{c}\text { Sept. } \\
1942 \\
\text { Feb. } \\
1943 \\
\end{array}$ & $\begin{array}{c}\text { Feb. } \\
1943 \\
? \\
\text { Nov. } \\
1943 \\
\end{array}$ & $\begin{array}{c}\text { Nov. } \\
1943 \\
\text { May } \\
1944\end{array}$ & $\begin{array}{c}\text { May } \\
1944 \\
\text { ? } \\
\text { Nov. } \\
1944 \\
\end{array}$ \\
\hline iya & 3 & & & & & & & & -3.6 & +3.5 & 0 & -2.1 & -1.7 \\
\hline Huku & 3 & & & & & & -14.8 & -7.6 & -7.8 & +0.9 & -2.2 & +3.7 & -2.2 \\
\hline $\mathrm{KW}$ & & -1.9 & -0.4 & +1.1 & -3.5 & $\begin{array}{l}+4.8 \\
\end{array}$ & -6.2 & +2.0 & -2.6 & +3.3 & +0.4 & +0.3 & -1.5 \\
\hline $\mathrm{KE}$ & & -1.2 & -1.2 & +1.7 & -3.9 & +4.6 & -5.8 & +2.0 & -2.7 & +3.4 & +0.4 & +0.3 & -1.6 \\
\hline Miya & 2 & & & & & & & & -12.4 & -0.3 & -6.1 & +5.0 & -3.7 \\
\hline Miy: & 1 & & & & & & & & -4.7 & +3.9 & -1.2 & +1.0 & -0.1 \\
\hline Kōzi & 2 & -2.2 & -3.9 & +2.8 & -4.4 & +3.3 & -8.9 & +3.3 & -5.5 & +5.6 & -0.7 & -1.5 & -19.5 \\
\hline M21W & & 6.2 & -6.3 & +1.7 & -7.7 & +2.7 & -9.6 & -2.9 & -6.6 & +3.0 & -0.6 & +1.0 & -2.6 \\
\hline $\mathrm{M} 21 \mathrm{E}$ & & -3.8 & -5.1 & +2.4 & -8.5 & +1.5 & -10.0 & -2.9 & -5.3 & +1.8 & -0.2 & +1.7 & -3.4 \\
\hline M21M & & -6.2 & -6.7 & +2.3 & -7.4 & +2.0 & -9.5 & -2.1 & -6.0 & +2.2 & -0.1 & +1.1 & -2.7 \\
\hline Kōzi & 3 & -22.9 & -8.4 & +0.2 & -15.3 & +5.4 & -21.4 & -3.2 & -12.4 & +7.7 & -3.2 & +6.4 & +0.1 \\
\hline A & & -27.5 & -11.9 & -0.3 & -20.3 & +3.6 & -24.6 & -9.7 & -14.5 & +6.0 & -7.1 & +6.4 & +0.6 \\
\hline $\mathrm{HE}$ & & -9.0 & -2.6 & +3.4 & -3.3 & +6.3 & -12.3 & +6.7 & -6.4 & +6.4 & -1.1 & +4.3 & -2.0 \\
\hline HW & & -8.9 & -2.6 & +3.8 & -3.5 & +6.7 & 2.7 & +7.3 & -6.4 & +7.4 & -0.8 & +4.6 & -2.7 \\
\hline Tetu & 1 & & & & & & -9.8 & +4.9 & -3.3 & +5.0 & -0.3 & +1.6 & -1.7 \\
\hline Tetu & 2 & & & & & & -12.8 & +5.3 & -6.5 & +7.1 & -0.4 & +2.1 & -1.5 \\
\hline Tetu & 3 & & & & & & -17.2 & +3.7 & -9.8 & +8.5 & -1.0 & +2.6 & -1.4 \\
\hline Tetu & $.3^{\prime}$ & & & & & & -14.4 & +5.3 & -8.2 & +7.5 & -0.9 & +1.2 & -1.1 \\
\hline Tetu & 4 & & & & & & -13.1 & +5.9 & -7.3 & +7.0 & -0.7 & +1.0 & -1.7 \\
\hline Tetu & 5 & & & & & & -9.9 & +6.0 & -5.5 & +5.5 & -0.3 & +1.2 & -2.4 \\
\hline $\mathrm{OE}$ & & -9.4 & -2.9 & +1.3 & -13.8 & +11.0 & -15.9 & +8.1 & -9.7 & +9.9 & -2.3 & +1.9 & -1.8 \\
\hline OW & & -13.2 & -2.0 & +1.0 & -13.7 & +10.5 & -17.3 & +4.9 & +10.0 & +8.8 & -2.1 & +1.9 & -0.9 \\
\hline OM & & -13.2 & -2.1 & +1.8 & -16.0 & +10.6 & -17.2 & +6.1 & -9.4 & +8.4 & -1.7 & +2.6 & -2.2 \\
\hline SE & & -5.8 & -2.5 & +4.3 & -9.8 & +10.3 & -12.0 & +6.8 & -6.7 & +6.7 & -0.9 & +2.4 & -3.2 \\
\hline $\mathrm{SW}_{1}$ & & ? & -3.8 & +4.5 & -9.6 & +9.5 & -10.5 & +6.8 & -4.5 & +3.9 & -0.9 & +2.6 & -4.9 \\
\hline $\mathrm{N}_{2}$ & & -3.3 & -3.8 & +3.7 & -8.2 & +9.3 & -10.8 & +6.1 & - & +6.2 & -0.9 & +2.3 & -4.5 \\
\hline$P^{\prime}$ & & -40.0 & -14.6 & -8.1 & -37.6 & -9.3 & -33.9 & -31.9 & -19.7 & +0.3 & -8.3 & +4.0 & -3.8 \\
\hline $\mathrm{P}^{\prime \prime}$ & & -27.3 & -9.8 & -6.8 & -47.5 & +2.5 & -31.7 & -17.5 & -15.3 & +3.3 & -7.4 & - & - \\
\hline Kozi & 4 & -0.3 & -2.9 & +2.0 & 2.1 & +2.9 & -4.3 & +1.2 & -1.1 & +1.5 & -0.6 & -0.4 & $=0.4$ \\
\hline
\end{tabular}


bench-marks in the area under consideration are shown in Fig. 1. The precise levels have been repeated over the area twelve times since May 1938.

The vertical displacements of the benchmarks found are given in Table $I$, the frist row of which shows the time interval during which they occurred.

In a previous paper (MYYABE and HukUnishr, 194.1), one of the present authors has already discussed the vertical movements of the surface of the ground in this same area which took place during 1938-1940. In the present paper, the study will be extended referring to the data given In Table I.

At a glance on Table I, we notice the following facts.

(1) Some of the time intervals are characteristic in that the vertical displacements of bench-marks which occurred during them are mostly positive.

(2) The natural sinking of the buildings are very small. This is especially true for the buildings of Toho Theatre (now Earny Pyle Theatre), Shisei Kaikan and Tokyo Marine Insurance Co., to which the benchmarks $\mathrm{HE}, \mathrm{HW}, \mathrm{SE}, \mathrm{SW}_{1}, \mathrm{SW}_{2}, \mathrm{KW}$ and $\mathrm{KE}$ are respectively fixed.

The foundations of most large buildings in this area are constructed in the manner as described below. After the ground surface is first excavated down to the depth of several meters, piles are driven into the depth of about 20 meters. The piles are usually concrete rods or pine logs, about 20 meters long and $16-20 \mathrm{~cm}$ in diameter. The base floor of most buildings is constructed on so piled foundation.

Since the soft alluvium soil layer in the area under consideration is about 20 meters in thickness, it is hardly practicable to set up the bench-marks directly on the hard and stable material which underlie the soil layer. The bench-marks situated in this area are mostly set up on the surface of the soft soil layer, except BM. Közi-4, which is believed to lie directly on the harder material, for, at this point, the thickness of the soft surface soil layrer is almost zero. The piles of the foundations of the buildings, on the other hand, probably reach the layer of the harder material underlying the surface soil layer. The buildings, the foundations of which are constructed as described above, are believed to be connected directly to the stable and harder layer.

The vertical displacements measured as have occurred during a certain time interval consist of two components, namely, a) the sinking of the surface due to the shrinkage of the soft soil, of which the overlying layer is composed, and b) the displacement resulting from tilt of the underlying layer. While the latter is quasi-periodic with respect to time, as will be shown later, the former is progressive as a whole, although the vertical displacements measured for relatively short intervals of time may occasionaly be positive. The relative up and downward movements of buildings, on the other hand, are likely to have almost nothing to do with the shrinkage of the soft soil layer.

In order to obtain the magnitude and azimuth of tilts of the ground surface, the values of $G$ are plotted against $\theta$ for each bench-mark. Here $G$ is the relative vertical displacement of a bench-mark with respect to BM. Közi-4 divided by the distance between these two bench-marks. $G$ will give therefore the component of tilt of the ground in the direction connecting the two bench-marks. On the other hand, $\theta$ is the azimuth of the line linking BM. Kōzi-4 with the bench-mark for

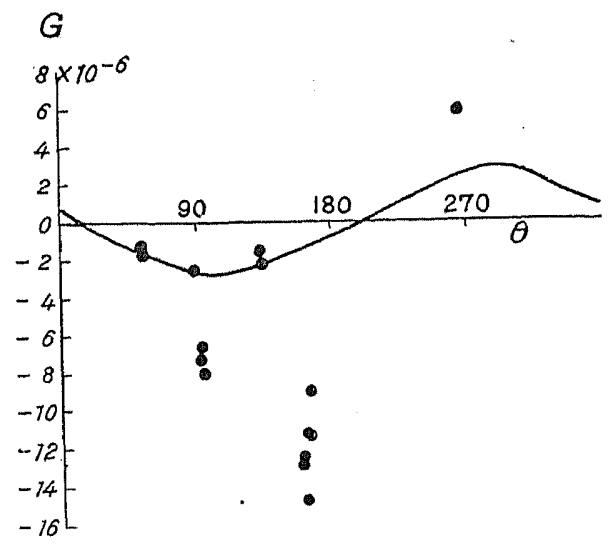

Fig. 2a. G-O diagram for displacements during June 1939-Nov. 1939. 
which $G$ is calculated. $\theta$ is measured in reference to $\mathrm{N}$. Two example of the plots are given in Fig. 2.

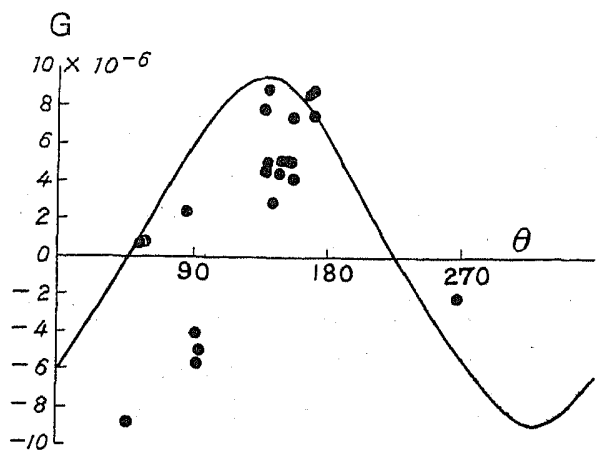

Fig. 2b. $G$-o diagram for displacements during Oct. 1940-Apr. 1943.

If the soft surface soil does not shrink and the earth's surface is as a whole tilted in a certain direction, a trigonometrical relation

$$
G=G_{m} \cos \left(\theta-\theta_{m}\right)
$$

must hold, where $G_{m}$ is the magnitude of tilt and $\theta_{m}$ is its direction. But in the case in which the vertical displacement is mainly produced by the sinking of the surface of the soft soil layer due to its shrinkage, the above relation may fail.

If the vertical displacements of the buildings of Toho Theatre, Shisei Kaikan and Tokyo Marine Insurance Co. are due to the tilting movements of the layer of material on which

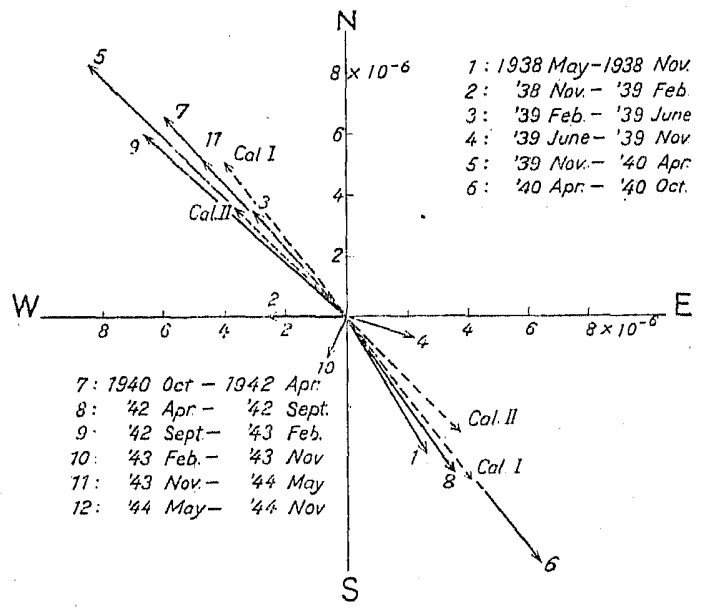

Fig. 3. Tilt vectors for separate time interval. they are built, a sinusoidal curve can be drawn in Fig. 2 through the points that correspond to the bench-marks fixed to these buildings. The sinusoidal curves in Fig. 2, which are drawn in this way, give the values of $G_{m}$ and $\theta_{m}$ of the tilts during the corresponding time intervals. The values of $G_{m}$ and $\theta_{m}$ for other time intervals were also determined similarly. Tilt vectors thus obtained corresponding to each time interval are shown by arrows in Fig. 3, while the successively integrated tilt vectors are shown by arrows in Fig. 4.

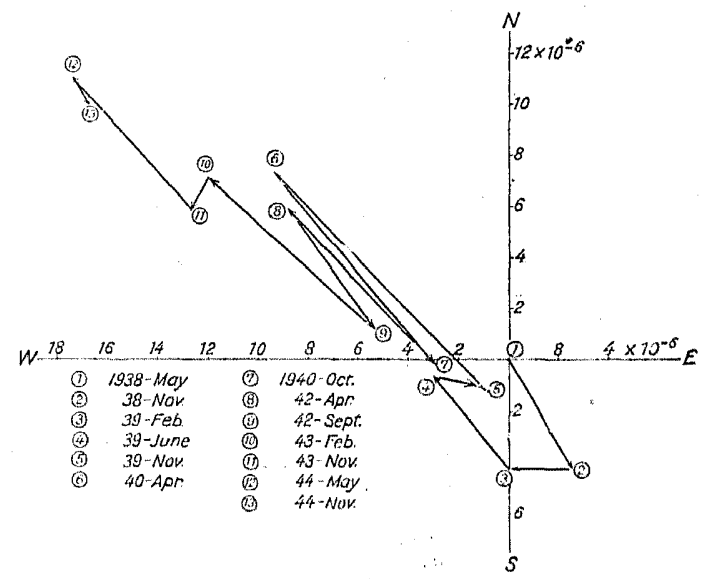

Fig. 4. Integrated tilt vector.

In Fig. 3, we notice that,

1) the tilts during winter time, i.e., the time interval from autumn to next spring, is in general directed to NW or away from the neighbouring sea, whereas tilts during summer time, i.e., the time interval from spring to autumn, is directed to SE, or towards the sea, and that

2) the vectors are very small in magnitude if their directions are deviated from NW-SE.

Such a behavior of tilts like this suggests that they may be due to the load of the annual tides of the sea water in the neighbouring Tokyo Bay.

Naturally the load of the sea water due to the diurnal and semi-diurnal tides has greater effect on the tilt of the ground surface than that due to the annual tide. The effect however is disregarded in the present study owing 
to the reason that the measurements of the heights of the bench-marks in question by precise levellings take more than a week, so that the influence of the diural and semidiurnal tides may be much smoothed out. Displacement components of a point in an elastic body caused by a distribution of load applied on its surface are given by Bousinese in the following form;

$u=-\frac{1}{4 \pi \mu} \frac{\partial^{2}}{\partial x \partial z} \int r d P-\frac{1}{4 \pi(\lambda+\mu)} \partial \int \log (z+r) d P$ $v=-\frac{1}{4 \pi \mu} \frac{\partial^{2}}{\partial y \partial z} \int r d P-\frac{1}{4 \pi(\lambda+\mu)} \frac{\partial}{\partial y} \int \log (z+r) d P$, $w=-\frac{1}{4 \pi / \iota} \cdot \frac{\partial^{2}}{\partial z^{2}} \int r d P-\frac{2 \lambda+3 \mu}{4 \pi \mu(\lambda+\mu)} \int \frac{d P}{r}$,

with customary notations.

Differentiating the vertical displacement $w$ at $z=0$ with respect to $x$, we have $x$-component of tilt of the surface of the elastic medium on which the load is distributed. Thus we have

$$
\partial w_{0}=\frac{\lambda+2 \mu}{4 \pi \mu(\lambda+\mu)} \partial x \int \frac{d P}{r} .
$$

Putting $d P=\rho g h d S$, we have

$$
\begin{aligned}
\partial w_{01} & =\frac{\lambda+2 \mu}{4 \pi \mu(\lambda+\mu)} \operatorname{\rho gh} \frac{\partial}{\partial x} \int \frac{d S}{r} \\
& =\lambda+2 \mu \\
& 4 \pi \mu(\lambda+\mu) \rho g h \iint \frac{\cos \theta}{r} d \theta d r \\
& =C У\left(\sin \theta_{m, m+1}-\sin 0^{\prime}{ }_{m, m+1}\right) \log \frac{r_{m+1}}{r_{m}},
\end{aligned}
$$

where $C$ stands for $\frac{\lambda+2 \mu}{4 \pi \mu(\lambda+\mu)} \rho g h, \rho$ is the density of the sea water, $h$ the amplitude of the annual tide, and $r$ the distance of an elementary load from the point under consideration. We have a similar expression also for $\begin{gathered}\partial w_{1} \\ \partial y\end{gathered}$.

For the constants in the above expression, the following numerical values were taken:

$$
\begin{aligned}
& \rho=1.0 \text {, } \\
& g=9.8 \times 10^{2} \mathrm{~cm} / \mathrm{sec}^{2} \\
& h=10 \mathrm{~cm} \\
& \mu=5 \times 10^{8} \text { c.g.s. } \\
& \lambda={ }_{1-2 \sigma}^{2 \sigma} \mu=15.8 \times 10^{8} \text { c.g.s. } \\
& \sigma=0.38 \text {, }
\end{aligned}
$$

The values of $\mu$ and $\sigma$ employed were taken from experimental results of Isнiмото and IrDA (1941). The value of $h$ is the round number of the amplitude of the annual tide observed by the Hydrographic Department at several mareographic stations along the coast of Tokyo Bay. To obtain the numerical value of tilt $\frac{\partial w_{0}}{\partial w}$, the extreme, value of $r$ should be assumed. By the extreme value of $r$ is meant such a distance that variations of sea water mass beyond it have no effect on the tilt of the earth's surface at the point in question.

If the extreme value of $r$ is taken as $40 \mathrm{~km}$, we have

$$
\begin{aligned}
& \frac{\partial w_{0}}{\partial x}=5.06 \times 10^{-6}, \\
& \frac{\partial w_{0}}{\partial y}=4.16 \times 10^{-6},
\end{aligned}
$$

whereas if it is taken as $25 \mathrm{~km}$., we have

$$
\begin{aligned}
& \frac{\partial w_{0}}{\partial x}=3.8 \times 10^{-0}, \\
& \frac{\partial w_{0}}{\partial y}=3.6 \times 10^{-6}
\end{aligned}
$$

The resultant vectors of these calculated tilts are shown respectively by dotted arrows, Cal. I and II, in Fig. 3. For still larger values of $r$, the calculated directions of tilt are much deviated from those observed. Whichever of the above two assumptions is taken as to the value of $r$, the calculated magnitude and azimuth of tilts agree well with those deduced from the observed data. Hence, it is likely that the actual vertical displacements measured by the levelling surveys are more or less modified by the elastic deformation of the earth's crust caused by the load of the annual tide. It is also suggested from the fact mentioned above that the annual tide of sea water within the distance of about 25-35 $\mathrm{km}$ from a point alone has effects on the tilt of the earth's surface at the point.

On subtracting from the total vertical displacements those due to the tidal loads, the residuals will represent the actual sinking of the earth's surface which may be due to the 
Table II. Revised Vertical Displacements of Bench-Marks in Hibiya and Marunouchi Area (in mm.).

\begin{tabular}{|c|c|c|c|c|c|c|c|c|c|c|c|c|c|}
\hline $\begin{array}{l}\text { In } \\
\text { B.M. }\end{array}$ & & $\begin{array}{c}\text { May } \\
1938 \\
? \\
\text { Nov. } \\
1938\end{array}$ & $\begin{array}{c}\text { Noy. } \\
1938 \\
\text { Feb. } \\
1939\end{array}$ & $\begin{array}{c}\text { Feb. } \\
1939 \\
\zeta \\
\text { June } \\
1939\end{array}$ & $\begin{array}{c}\text { June } \\
1939 \\
? \\
\text { Nov. } \\
1939\end{array}$ & $\begin{array}{c}\text { Nov. } \\
1939 \\
? \\
\text { Apri1 } \\
1940\end{array}$ & $\begin{array}{c}\text { April } \\
1940 \\
2 \\
\text { Oct. } \\
1940\end{array}$ & $\begin{array}{c}\text { Uct. } \\
1940 \\
\text { Apri1 } \\
1942\end{array}$ & $\begin{array}{c}\text { April } \\
1942 \\
\text { Sept. } \\
1942\end{array}$ & $\begin{array}{c}\text { Sept. } \\
1942 \\
\text { Feb. } \\
1943\end{array}$ & $\begin{array}{c}\text { Feb. } \\
1943 \\
1 \\
\text { Nov. } \\
1943\end{array}$ & $\begin{array}{c}\text { Nov. } \\
1943 \\
\text { ? } \\
\text { May } \\
1944\end{array}$ & $\begin{array}{c}\text { Ilay } \\
1944 \\
? \\
\text { Nov. } \\
1944\end{array}$ \\
\hline Miya & 3 & & & & & & & & -2.7 & +0.3 & -1.3 & -0.1 & -1.4 \\
\hline Huku & 3 & & & & & & -11.3 & -10.9 & -6.8 & -3.7 & -3.8 & +1.2 & -1.8 \\
\hline $\mathrm{KW}$ & & -1.2 & -3.8 & -0.4 & -1.6 & -1.3 & -1.4 & -1.5 & -1.2 & -1.8 & -1.1 & -2.4 & -1.0 \\
\hline $\mathrm{KE}$ & & -0.3 & -3.6 & -0.3 & -1.9 & -2.1 & -2.1 & -2.4 & -1.0 & -2.3 & -1.1 & -3.1 & -1.0 \\
\hline Miya & 2 & & & & & & & & -9.8 & -6.2 & -6.8 & +0.9 & -3.0 \\
\hline Miya & 1 & & & & & & & & -2.7 & -0.6 & -1.7 & -2.1 & +0.4 \\
\hline Kōzi & 2 & +1.0 & -7.3 & -1.2 & -2.0 & -8.1 & -0.7 & -4.8 & -1.6 & -3.4 & -1.5 & -7.8 & -18.4 \\
\hline M21W & & -3.0 & -9.4 & -2.2 & -5.5 & -8.2 & -1.6 & -10.7 & -2.7 & -5.5 & -1.3 & -5.0 & -1.6 \\
\hline $\mathrm{M} 21 \mathrm{E}$ & & -0.6 & -8.4 & 1.7 & -6.2 & -9.9 & -1.6 & -11.0 & -1.3 & -7.1 & -0.9 & -4.6 & -2.3 \\
\hline $\mathrm{M} 21 \mathrm{M}$ & & -2.9 & -9.9 & -1.8 & -5.2 & -9.3 & -1.1 & -10.2 & -2.0 & -6.7 & -0.8 & -5.2 & +1.6 \\
\hline Kōzi & 3 & -18.6 & $-11 \cdot 1$ & -4.5 & -13.4 & -7.0 & -11.4 & -12.3 & -7.5 & -1.8 & -3.3 & -2.8 & +1.2 \\
\hline A & & -23.1 & -14.5 & -5.0 & -18.4 & -8.7 & -14.7 & -18.8 & -9.7 & -3.4 & -7.2 & -0.6 & +1.8 \\
\hline $\mathrm{HE}$ & & -4.4 & -5.1 & -1.5 & -1.4 & -6.2 & -1.1 & -2.6 & -1.6 & -3.2 & -1.0 & -2.9 & -0.8 \\
\hline $\mathrm{HW}$ & & 4.4 & -5.0 & -1.0 & -1.7 & -6.1 & -2.7 & -1.8 & -1.5 & -2.7 & -0.7 & -2.4 & -1.5 \\
\hline Tetu & 1 & & & & & & +1.5 & .2 & - & -5.5 & -0.2 & -6.3 & -1.3 \\
\hline $\mathrm{Te}$ & 2 & & & & & & -1.4 & -5.0 & -0.9 & -3.4 & -0.2 & -5.9 & -0.3 \\
\hline Tetu & 3 & & & & & & -5.4 & -6.9 & -4.0 & -2.2 & -0.7 & -5.6 & -0.1 \\
\hline $\mathrm{Te}$ & $3^{\prime}$ & & & & & & -2.3 & -5.5 & -2.3 & -3.4 & -0.6 & -7.1 & -0 \\
\hline Tetu & 4 & & & & & & -0.8 & -5.1 & -1.3 & -4.0 & -0.8 & -7.5 & +0.4 \\
\hline $\mathrm{T}$ & 5 & & & & & & +3.1 & -5.1 & +0.7 & -5.7 & +0.2 & -7.4 & -0.2 \\
\hline $\mathrm{OE}$ & & -3.6 & -5.0 & -4.5 & -12.1 & -3.5 & -3.5 & -2.8 & $-3.5 \mid$ & -0.9 & -1.7 & -6.5 & -0.9 \\
\hline ow & & 7.5 & -4.0 & -4.6 & -12.1 & -14.3 & -5.8 & -5.6 & -4.0 & -1.7 & -1.5 & -6.2 & -0.7 \\
\hline OM & & -7.4 & -4.2 & -4.2 & -14.3 & -3.8 & -4.9 & -4.7 & -3.2 & -1.2 & -1.1 & -5.8 & +0.5 \\
\hline SE & & 1.3 & -4.2 & -0.1 & -8.5 & -0.9 & -2.5 & -1.6 & -2.0 & -1.7 & -0.5 & -3.7 & -1.1 \\
\hline $\mathrm{SW}_{1}$ & & +1.1 & -5.4 & +0.2 & -8.3 & -1.3 & -1.3 & -2.3 & -0 & -4.2 & -0.5 & -3.7 & -1.9 \\
\hline SV & & +1.1 & -5.4 & -0.6 & -7.1 & -1.5 & -1.6 & -2.0 & -2.1 & -1.9 & -0.4 & -4.0 & -3.6 \\
\hline $\mathrm{P}^{\prime}$ & & -35.2 & -16.2 & -12.7 & -36.4 & -21.3 & -23.9 & -40.7 & -14.3 & -8.5 & -7.8 & -2.8 & -3.9 \\
\hline $\mathrm{P}^{\prime \prime}$ & & -25.9 & -11.4 & -11.2 & -46.4 & -8.4 & -22.4 & -25.7 & -10.7 & -4.8 & -6.9 & - & - \\
\hline Kōzi & 4 & +0.9 & -4.2 & +0.5 & -1.7 & -1.3 & -1.3 & -1.8 & +0.3 & -1.8 & -0.9 & -2.7 & () \\
\hline
\end{tabular}


shrinkage of the surface layer of soft soil. These residual vertical displacements are given in Table II.

As may be seen in the above table, the values are mostly negative, showing that most bench-marks sunk during each of successive time intervals.

In Table II, the sinking of the bench- marks, $\mathrm{P}^{\prime}, \mathrm{P}^{\prime \prime}, \mathrm{A}$ and Közi-3 are especially remarkable. To see the general tendency of: the sinking of the earth's surface in the area under consideration, the average values of monthly sinking rates of the four benchmarks mentioned above are calculated and are given in Table III.

Table III. Average Sinking of Bench-Marks P', P', A and Kōzi-3.

\begin{tabular}{|c|c|c|c|c|c|c|c|c|c|c|c|c|}
\hline Period & $\begin{array}{c}\text { May } \\
1938 \\
\text { ? } \\
\text { Nov. } \\
1938\end{array}$ & $\begin{array}{c}\text { Nov. } \\
1938 \\
? \\
\text { Feb. } \\
1939\end{array}$ & $\begin{array}{c}\text { Feb. } \\
1939 \\
\vdots \\
\text { June } \\
1939\end{array}$ & $\begin{array}{c}\text { June } \\
1939 \\
\text { ? } \\
\text { Nov. } \\
1939\end{array}$ & $\begin{array}{c}\text { Nov. } \\
1939 \\
? \\
\text { April } \\
1940\end{array}$ & $\begin{array}{c}\text { April } \\
1940 \\
\text { Oct. } \\
1940\end{array}$ & $\begin{array}{c}\text { Oet. } \\
1940 \\
\text { April } \\
1942\end{array}$ & $\begin{array}{c}\text { April } \\
1942 \\
\text { Sept. } \\
1942\end{array}$ & $\begin{array}{c}\text { Sept. } \\
1942 \\
\text { ? } \\
\text { Feb. } \\
1943\end{array}$ & $\begin{array}{c}\text { Feb. } \\
1943 \\
\text { ? } \\
\text { Nov. } \\
1943\end{array}$ & $\begin{array}{c}\text { Nov. } \\
1943 \\
\text { May } \\
\text { 1944 }\end{array}$ & $\begin{array}{c}\text { May } \\
1944 \\
\text { ? } \\
\text { Nov. } \\
1944\end{array}$ \\
\hline $\mathrm{mm} / \mathrm{month}$ & 4.3 & 4.4 & 2.1 & 5.7 & 2.3 & 3.0 & 1.4 & 2.1 & 0.9 & 0.7 & 0.3 & 0.4 \\
\hline
\end{tabular}

We notice in Table III that,

1) the monthly rate of sinking has been gradually decreasing,

and that

2) in the interval involving summer and autumn, the rates are larger than in the intervals involving winter and spring.

In conclusion, the writers wish to express their sincere thanks to the Municipal Authority of Tokyo who has supplied the valuable data of levellings and placed them at our disposal.

\section{References}

Ishimoto, M., and IIDA, K. :

1936 Determination of Elastic Constants of Soils by means of Vibration Methods. Bull. Earthq. Res. Inst., 14, 632-656.

Mryabe, N., and Hukunishr, S.:

1941 Results of Relevelling in Tokyo in 1940. Bull. Earthq. Res. Inst., 19, 248-259, 